Article

\title{
Environmental Decision Support System for Biogas Upgrading to Feasible Fuel
}

\author{
Eric Santos-Clotas, Alba Cabrera-Codony®, Alba Castillo, Maria J. Martín, Manel Poch and \\ Hèctor Monclús * \\ LEQUIA, Institute of Environment, University of Girona, Maria Aurèlia Capmany, 69. Campus Montilivi, \\ Girona, E17003 Catalonia, Spain; eric.santos@udg.edu (E.S.-C.); alba.cabrera@udg.edu (A.C.-C.); \\ albacastillorens@hotmail.com (A.C.); maria.martin@udg.edu (M.J.M.); manuel.poch@udg.edu (M.P.) \\ * Correspondence: hector.monclus@udg.edu; Tel.: +34-972418162
}

Received: 20 March 2019; Accepted: 18 April 2019; Published: 24 April 2019

\begin{abstract}
Biogas production is a growing market and the existing conversion technologies require different biogas quality and characteristics. In pursuance of assisting decision-makers in biogas upgrading an environmental decision support system (EDSS) was developed. Since the field is rapidly progressing, this tool is easily updatable with new data from technical and scientific literature through the knowledge acquisition level. By a thorough technology review, the diagnosis level evaluates a wide spectrum of technologies for eliminating siloxanes, $\mathrm{H}_{2} \mathrm{~S}$, and $\mathrm{CO}_{2}$ from biogas, which are scored in a supervision level based upon environmental, economic, social and technical criteria. The sensitivity of the user towards those criteria is regarded by the EDSS giving a response based on its preferences. The EDSS was validated with data from a case-study for removing siloxanes from biogas in a sewage plant. The tool described the flow diagram of treatment alternatives and estimated the performance and effluent quality, which matched the treatment currently given in the facility. Adsorption onto activated carbon was the best-ranked technology due to its great efficiency and maturity as a commercial technology. On the other hand, biological technologies obtained high scores when economic and environmental criteria were preferred. The sensitivity analysis proved to be effective allowing the identification of the challenges and opportunities for the technologies considered.
\end{abstract}

Keywords: EDSS; biogas upgrading; renewable energies; siloxanes; hydrogen sulfide

\section{Highlights}

- $\quad$ BiogasApp_EDSS is a tool considering a wide spectrum of parameters simultaneously

- $\quad$ The EDSS is structured hierarchically to simplify the flow and interactions of data and knowledge

- $\quad$ The EDSS has been validated with a real case-study

- The sensitivity analysis allowed identifying key criteria

- Biotechnologies were competitive alternatives when economic criteria were concerned

\section{Introduction}

The necessity to find sustainable resources that assist initiatives to reduce global warming is paramount. One of the most challenging issues is the replacement of fossil fuels in order to reduce greenhouse gas (GHG) emissions. There are already some directives, such as the Biofuels Directive (2015/1513) (European Parliament, 2015), promoting the use of renewable biofuels within the European Union (EU) Member States, aiming to minimize the dependency on oil-based fuels. In this context, biogas form many landfills and wastewater treatment plants (WWTP) is being collected and used as a renewable fuel to obtain energy $[1,2]$. 
Biogas is generated from the anaerobic digestion of sewage sludge in wastewater treatment plants, the organic fraction from municipal solid wastes, livestock residues or organic agroindustry wastes [3-5]. The major component of biogas is methane $(50-70 \%)$ and its content determines the energetic value of the biogas produced. However, as a result of the anaerobic digestion other compounds compose biogas and the composition of the final gas depends on the origin and characteristics of the substrate $[6,7]$. In this sense, the other main compound in biogas is $\mathrm{CO}_{2}(30-50 \%)$ followed by other gases under $2 \%$ (oxygen, nitrogen, hydrogen sulfide, etc.). Trace concentrations of aromatic hydrocarbons and siloxanes are often present in biogases from anaerobic digesters in WWTPs and landfills as well $[8,9]$.

Biogas is commonly used for heat, steam or electricity generation. In the EU, the most common energy conversion systems (ECS) applied to biogas are combined heat and power (CHP) internal combustion engines, gas micro-turbines, or large turbines, in which biogas does not need to be extensively upgraded. Obtaining energy from biogas by means of electrochemical reactions in fuel cells is also a highly efficient system, although elevated methane content in biogas is required [10,11]. There are further applications, such as vehicle fuel or grid injection, that require high-energy content gas. In order to be used for these purposes, biogas needs to be upgraded by removing $\mathrm{CO}_{2}$, leading to the so-called biomethane [12]. Hence, biogas generates new possibilities for its use since it can meet the same technical requirements than natural gas $[13,14]$.

Therefore, depending on the end use, different upgrading steps are necessary. $\mathrm{H}_{2} \mathrm{~S}$, found at high concentrations: up to $100 \mathrm{ppm} v / v$ in landfill gas and to $40,000 \mathrm{ppm} v / v$ in sewage sludge gas $[15,16]$, is a corrosive gas that must be removed before the use of biogas in most applications. $\mathrm{H}_{2} \mathrm{~S}$ removal technologies include catalytic adsorption onto impregnated activated carbon (AC), biological technologies (i.e., biotrickling filter, biofilter), absorption (physical or chemical scrubbers), and chemical oxidation [17-19].

Besides $\mathrm{H}_{2} \mathrm{~S}$ abatement, the removal of siloxanes is mandatory in biogas upgrading [20,21]. Siloxanes are a group of polymeric compounds of Si-O bonds with organic side chains attached to each silicon atom. During biogas combustion within the ECS, siloxanes are converted into microcrystalline silica $\left(\mathrm{SiO}_{2}\right)$, which may inhibit heat conduction or lubrication as well as abrade engine parts. Typical siloxane concentration ranges from 10 to $120 \mathrm{mg} \mathrm{m}^{-3}$ [15]. Physical absorption, currently commercial for siloxane elimination, accomplishes moderate elimination efficiencies and is usually combined with other treatments such as refrigeration [22]. Non regenerative adsorption onto AC is the most widely used to reduce siloxane concentration [23], since it is low energy-consuming and highly effective [24]. Biotrickling filters and membrane separation systems are emerging techniques, although currently under research [25].

If the final application of this resource is to be injected to the national gas grid or as a vehicle fuel, additional requirements need to be overcome [26]. For this purpose, methane must be practically the only component of the gas, while the $\mathrm{CO}_{2}$ content admitted depends on each country's legislation. The state-of-the-art for removing $\mathrm{CO}_{2}$ from biogas at industrial scale is mostly carried out by physical/chemical technologies such as membrane separation and scrubbing $[27,28]$. On the other hand, the potential of biotechnologies has been evaluated at laboratory or pilot scale so far [29-31].

The biogas market is rapidly evolving: due to the intense research focused on this field, many technologies have been developed for improving biogas quality. Many chemical/physical and biological technologies have advanced and are currently ready to be employed in landfills and WWTPs [32]. However, the selection of the most appropriate treatment in each specific case is a complex task still unsolved. The main difficulties encountered in the decision system are: (i) the number of technologies that have been implemented, (ii) the fact that different technologies imply similar costs [33] and (iii) the necessity to consider different type of criteria to ensure an integrated analysis (i.e., economic, technical, and environmental).

Environmental decision support systems (EDSS) are intelligent information systems that help users choose a consistent solution for a singular problem in a shortened time frame [34] in environmental domains. These tools have gained interest and popularity within the wastewater management sector [35]. They have already been successfully applied in the decision process of wastewater treatment technologies in real facilities [36]. 
EDSS have been developed in the last years to assist decision-making processes [34] as a result of the need to cope with the difficult systematization of these elements and complexities all at once [35]. Several models have been developed, specially devoted to wastewater management, though focusing in completely different objectives and some tools are already available to select, for instance, the best wastewater treatment alternatives for specific cases [37,38]. The construction of an EDSS depends on the type of problem and knowledge that may be acquired. Several methodologies can be found in the literature $[39,40]$ although most of them in the environmental domain have in common some steps for any kind of EDSS deployment: (1) determine stakeholders, decision makers, and modelers; (2) develop the problem; (3) collect/analyze data; (4) select the convenient model; and (5) implement and validate the EDSS.

In the biogas field, Billig and Thrän (2016) developed a multi-criteria analysis tool that evaluates complex technical and economic issues regarding biomethane production from biomass. On the other hand, Estrada et al., (2012) [41] developed a sensitivity analysis evaluating technology designing parameters and commodity prices for odor abatement technologies. They reported that biological technologies showed lower sensitivity and operating costs than physical/chemical technologies. Nevertheless, there is a lack of tools to systematize the decision-making process to help decision-makers to select biogas upgrading treatment alternatives.

Hence, the objective of this work is to present the knowledge-based EDSS to support the selection of the most convenient technologies to remove specific pollutants from biogas (i.e., siloxanes, $\mathrm{H}_{2} \mathrm{~S}$, $\mathrm{CO}_{2}$ ) and convert it into a feasible fuel for each application. Moreover, this paper aims at describing the operation of the EDSS and its validation in a real case study as well as evaluating its sensitivity towards the used technical, economic and environmental criteria.

\section{Methodology}

\subsection{EDSS Operation}

\subsubsection{Knowledge and Data Acquisition Level}

The knowledge and data acquisition level requires the key information (data and knowledge), aiming to define the problem for proposing an objective decision. In that sense, this level includes the data introduced by the EDSS user to define the scenario regarding raw biogas characteristics, i.e., biogas flowrate and composition (Figure 1 "Raw biogas").

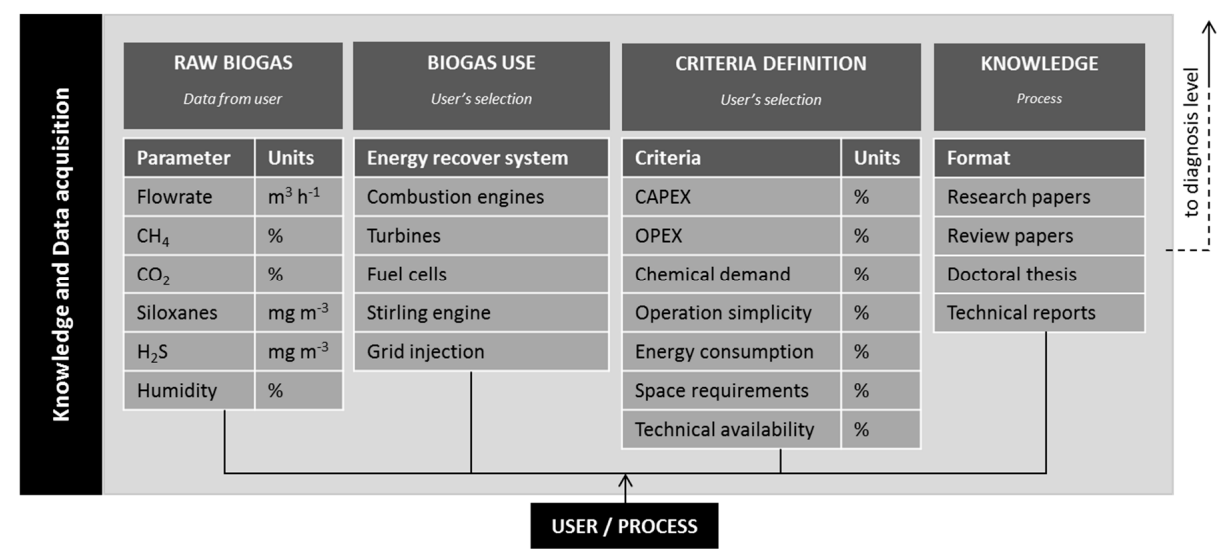

Figure 1. Scheme diagram of knowledge and data acquisition level. CAPEX: capital expenses; OPEX: operating expenses.

Depending on the final exploitation of biogas selected by the EDSS user, the quality requirements regarding $\mathrm{CH}_{4}$, siloxanes and $\mathrm{H}_{2} \mathrm{~S}$ composition are defined (Figure 1 "Biogas use") according to the requirements of the technology manufacturers, summarized in Table 1. 
Table 1. Concentration limits of each compounds according to quality requirements of different energy conversion systems [13,16,22,42,43]. ICE: internal combustion engine; PAFC: phosphoric acid fuel cell; SOFC: solid oxide fuel cell.

\begin{tabular}{lllll}
\hline ECS & Type & $\begin{array}{l}\text { Total Siloxane } \\
\text { Limit }\left(\mathbf{m g ~ m}^{-3}\right)\end{array}$ & $\mathbf{H}_{\mathbf{2}} \mathbf{S}$ Tolerance $\left(\mathbf{m g ~ m}^{-3}\right)$ & $\begin{array}{l}\text { Need to Convert } \\
\mathbf{C O}_{\mathbf{2}} \text { to } \mathbf{C H}_{4}\end{array}$ \\
\hline $\begin{array}{llll}\text { Internal } \\
\text { combustion engine }\end{array}$ & Permissive ICE & 30 & 695 & No \\
Micro-turbine & Restrictive ICE & 12 & 70 & No \\
Fuel cells & Capstone & 0.03 & 6900 & No \\
& PAFC & 0.1 & 28 & No \\
Stirling engine & SOFC & 0.01 & 1.4 & No \\
Grid injection & Standard & No limit & 1390 & No \\
\hline
\end{tabular}

The EDSS user defines the prioritization of different criteria (Figure 1 "Criteria definition") in other to obtain a technologic solution based on user's criteria.

Finally, this level includes an exhaustive scientific and technical literature revision (Tables S1-S3 in the Supplementary Materials) of the technologies capable of removing the target compounds (siloxanes, $\mathrm{H}_{2} \mathrm{~S}$ and $\mathrm{CO}_{2}$ ). The knowledge uploaded in this level is the fundamental data base for choosing the suitable technologies in the diagnosis level (Figure 1 "Knowledge").

The technologies considered in this level are summarized in Table 2, and they can be manually and easily incorporated in the EDSS knowledge level if new technical and scientific data is available, as well as new treatment technologies come up.

Table 2. Technologies contemplated within the environmental decision support system (EDSS) knowledge $[18,20,22,27,28,31,44-49]$.

\begin{tabular}{|c|c|}
\hline Technology & Brief Description \\
\hline \multicolumn{2}{|r|}{$\mathrm{H}_{2} \mathrm{~S}$ removal } \\
\hline In-situ precipitation & FeS formation by addition of $\mathrm{Fe}^{2+} / \mathrm{Fe}^{3+}$ \\
\hline Adsorption- $\mathrm{Fe}_{2} \mathrm{O}_{3} / \mathrm{Fe}(\mathrm{OH})_{3}$ & Chemical adsorption based in regenerable $\mathrm{Fe}_{2} \mathrm{O}_{3}, \mathrm{Fe}(\mathrm{OH})_{3}$ or $\mathrm{ZnO}$. \\
\hline Membrane separation & Selective permeation of $\mathrm{H}_{2} \mathrm{~S}$ through membrane and retention of $\mathrm{CH}_{4}$ \\
\hline Absorption- $\mathrm{NaOH} / \mathrm{H}_{2} \mathrm{O}$ & Conversion to elemental sulfur/metal sulfides by basic or water scrubbing \\
\hline Biotrickling filter (BTF) & Biological removal through bacteria in packed bed column after gas-liquid mass transfer \\
\hline In-situ microaerobic & Sulphide oxidizing bacteria grown over the wall and ceiling \\
\hline Thiopaq $^{\circledR}$ (Paques, NL) & $\begin{array}{l}\text { Absorption in a caustic solution, followed by oxidation to } S \text { by autotrophic bacteria, which is later } \\
\text { separated as a byproduct. }\end{array}$ \\
\hline Biopuric ${ }^{\circledR}$ (Veolia, USA) & Sulfur oxidizing microorganisms metabolize $\mathrm{H}_{2} \mathrm{~S}$ into elemental sulfur and sulfuric acid. \\
\hline Microalgae-based & Simultaneous removal of $\mathrm{CO}_{2}$ and $\mathrm{H}_{2} \mathrm{~S}$ by the symbiosis of algae and bacteria in photobioreactors. \\
\hline \multicolumn{2}{|r|}{ Siloxanes removal } \\
\hline AC adsorption & Physical adsorption of siloxanes onto activated carbon. \\
\hline Inorganic adsorption & Physical adsorption of siloxanes onto zeolites or silica gel. \\
\hline Biotricking filters & Biological removal through bacteria in packed bed column after gas-liquid mass transfer \\
\hline Fluidized bed adsorption & $\begin{array}{l}\text { Siloxane adsorption in a porous material where a part of the bed is continuously regenerated by } \\
\text { stripping. }\end{array}$ \\
\hline Organic solvent scrubber & Siloxanes absorption into organic solvents in spray or packed bed towers. \\
\hline Absorption-strong acids & Reactive absorption using concentrated acid solutions $\left(\mathrm{HNO}_{3}\right.$ and $\left.\mathrm{H}_{2} \mathrm{SO}_{4}\right)$ \\
\hline Membranes & Selective siloxane permeation through diffusion through dense inorganic or polymeric membranes. \\
\hline Deep chilling & Separation by decreasing temperature below $/ 25^{\circ} \mathrm{C}$ depending on siloxane saturation partial pressure. \\
\hline \multicolumn{2}{|r|}{$\mathrm{CO}_{2}$ Conversion/removal } \\
\hline Water scrubbing & $\mathrm{CO}_{2}$ absorption in water based on its higher aqueous solubility than $\mathrm{CH}_{4}$. \\
\hline Organic solvent scrubbing & Absorption in polyethylene glycol-based high affinity absorbents. \\
\hline Chemical scrubbing & Chemical absorption into alkanol amines/alkali aqueous solutions. \\
\hline Pressure swing adsorption & $\begin{array}{l}\text { Selective adsorption of } \mathrm{CO}_{2} \text { over } \mathrm{CH}_{4} \text { and periodical desorption in different adsorbers for } \\
\text { regeneration purposes }\end{array}$ \\
\hline Membranes & Selective permeation through diffusion through dense inorganic or polymeric membranes. \\
\hline Cryogenic separation & Separation by decreasing temperature below $-55^{\circ} \mathrm{C}$ to liquefy $\mathrm{CO}_{2}$. \\
\hline $\begin{array}{l}\text { Chemoautotrophic } \\
\text { upgrading }\end{array}$ & Bioconversion of $\mathrm{CO}_{2}$ to $\mathrm{CH}_{4}$ by hydrogenotrophic methanogens providing an external $\mathrm{H}_{2}$ injection. \\
\hline Photosynthetic upgrading & $\begin{array}{l}\text { Biomass fixation by eukaryotic microalgae and cyanobacteria, helped by the electrons released during } \\
\text { water photolysis. }\end{array}$ \\
\hline In situ desorption & $\begin{array}{l}\text { Separation by stripping away the } \mathrm{CH}_{4} \text { in a desorption unit taking advantage of the higher solubility of } \\
\text { the } \mathrm{CO}_{2} \text {. }\end{array}$ \\
\hline
\end{tabular}




\subsubsection{Diagnosis of Treatment Technologies Level}

This level is the responsible for carrying out a pre-screening of the feasible technologies to be applied to each pollutant according to their removal efficiencies. Based on the data and knowledge previously acquired, the removal efficiencies that can be achieved by each technology are calculated according the final use of the biogas and their requirements (Figure 2). Only the technologies that meet the effluent application requirements are considered in the following level (supervision) using rule-based methodology $[7,9,14,36]$.

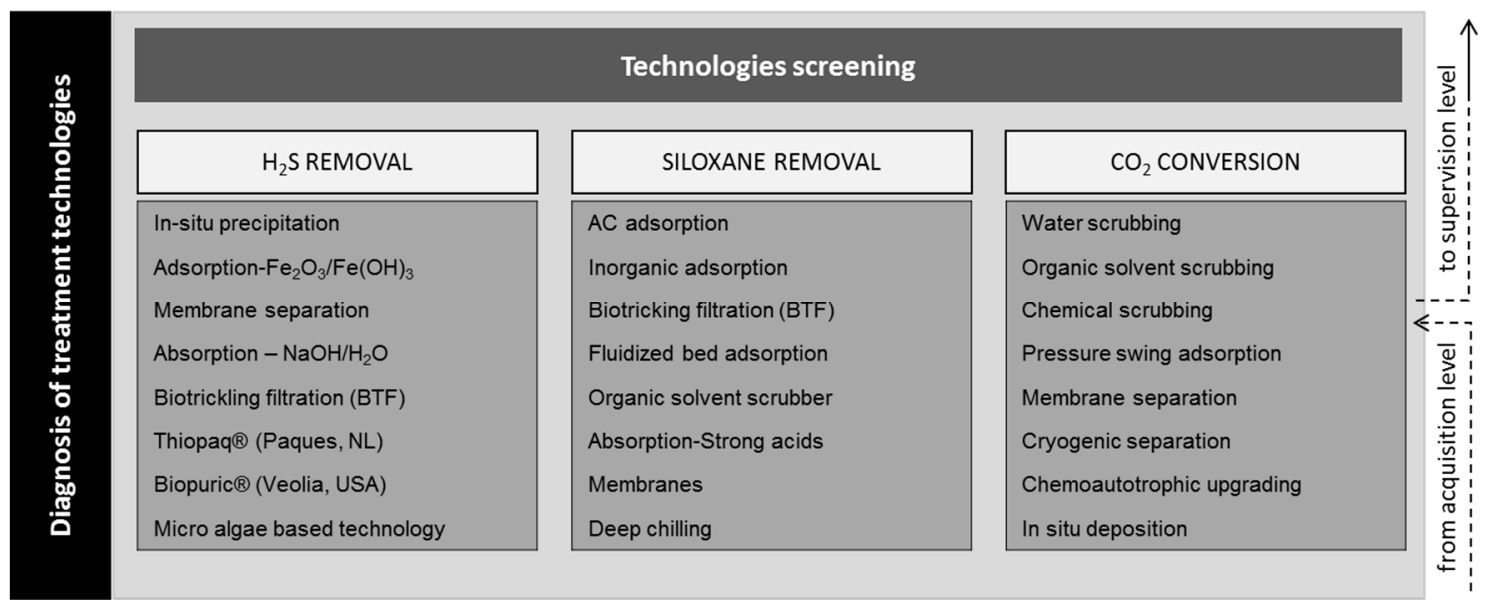

Figure 2. Scheme diagram of the diagnosis level.

\subsubsection{Knowledge-Based Supervision Level}

The objective of this level is to evaluate, based on the multi-criteria analyses, the technologies preselected in the diagnosis level. The EDSS users must select their preferred criteria (objectives) and give them a weight based on own preferences: environmental, economic or technical. The total weight should come to 100 (Figure 1).

This level applies a fuzzy logic methodology to measure a Rating $(R)$ for every criterion and the consequent Score (S) for each one of the feasible technologies. The data available to calculate the rating for every criterion is either qualitative or quantitative depending on the existing technical and scientific literature of every technology. When qualitative data is available, the rating is distributed according to Figure 3, where the most favorable scenario receives the highest rating.

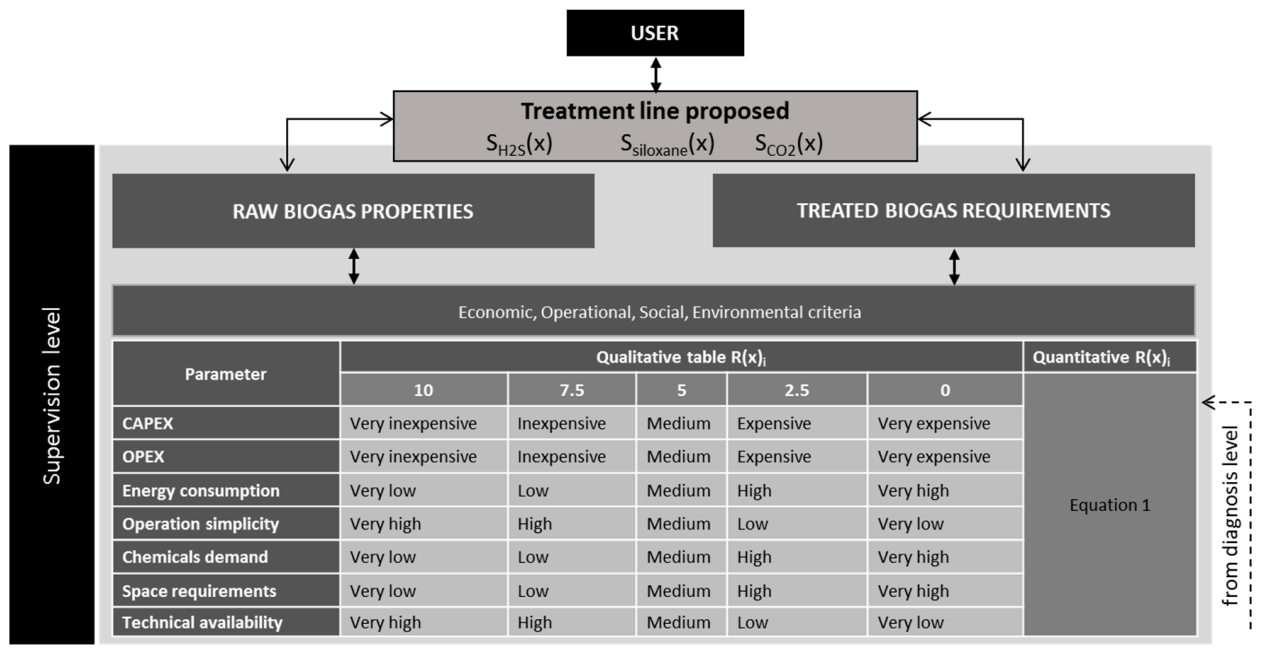

Figure 3. Scheme diagram of the supervision level where the score is calculated based on the multi-criteria analysis. 
Fuzzy logic methodology easily permits to implement a categorization based on human reasoning (very high, high, medium, low, and very low), and consequently a numerical value is assigned. When quantitative data for a given criterion is available, the rating is calculated according to Equation (1). In these cases, 10 points over 10 are given to the most appropriate technology $\left(R_{i}=10\right), 0$ to the most unfavorable one $\left(R_{i}=0\right)$ and a normalization process is applied to calculate the rating of the technologies with intermediate values for that criterion.

$$
R(x)_{i}=\left[\frac{\left(V_{w t}-V_{i t}\right)}{\left(V_{w t}-V_{b t}\right)}\right] \times 10
$$

where:

- $R(x)_{i}$, is the resulting rating for one intermediate technology $\mathrm{x}$ regarding criterion $\mathrm{I} ;$

- $V_{i t}$, is the quantitative value for the intermediate technologies;

- $V_{w w}$, is the quantitative value for the worst technologies;

- $V_{b t}$, is the quantitative value for the best technologies.

Thus, considering the rating obtained in each criterion and the weight given by the user, the total score for each technology in the multi-criteria analysis is calculated by Equation (2) as the sum of the rating multiplied by its given weight.

$$
S(X)=\sum_{i=1}^{n} \frac{W_{i}}{100} \cdot R(x)_{i}
$$

where:

- $S(X)$, is the score calculated by BiogasApp_EDSS for a technology $\mathrm{X}$;

- $W_{i}$, is the weight given to one criterion (Figure 3);

- $R(x)_{i}$, is the rating obtained in the criterion;

- $n$, is the total number of criteria considered.

Considering the weight that the user gives to every operation unit, the combination of $\mathrm{H}_{2} \mathrm{~S}$, siloxane, and $\mathrm{CO}_{2}$ technologies, plus pre-treatment when required, BiogasApp_EDSS gives the flow diagram. The user interface allows the BiogasApp_EDSS to interact with the user and analyze the response given generating if-then scenarios, i.e., change the criteria weights, the influent flow and concentration, the effluent quality required, or a combination of those, to get an integrated assessment.

\subsection{Case Study Validation}

A conventional urban WWTP from the Barcelona metropolitan area (Barcelona, Spain) was chosen as real case-study to test the results generated with the BiogasApp_EDSS. This facility treats the wastewater from ca. 135,000 equivalent inhabitants and collects the biogas generated by the anaerobic digestion of the sewage sludge produced. Gas flowrate and composition values for the raw biogas are gathered in Table 3. Currently, in this facility three C65 microturbines (Capstone Turbine Corporation) are being used for electricity production, generating $60 \%$ of the electric power consumed in the whole WWTP. 
Table 3. Values for the raw biogas generated in the case-study wastewater treatment plant (WWTP) (personal communication).

\begin{tabular}{lll}
\hline Parameter & Value Raw Biogas & Units \\
\hline Flowrate & 110 & $\mathrm{~m}^{3} \mathrm{~h}^{-1}$ \\
$\mathrm{CH}_{4}$ & $65^{\mathrm{b}}$ & $\%$ \\
$\mathrm{CO}_{2}$ & $35^{\mathrm{b}}$ & $\%$ \\
Siloxanes & 20 & $\mathrm{mg} \mathrm{m}^{-3}$ \\
$\mathrm{H}_{2} \mathrm{~S}$ & 500 & $\mathrm{mg} \mathrm{m}^{-3}$ \\
Humidity & 97 & $\%$ \\
\hline
\end{tabular}

The facility is currently using activated carbon adsorption filters to remove siloxanes, with a prior pretreatment to remove humidity. The BiogasApp_EDSS was run to study the most appropriated raw biogas treating technologies for this case of study considering the quality requirements gathered in Table 3 for this ECS considering equally capital expenses (CAPEX), operating expenses (OPEX), removal efficiency (RE), and the stage of development of the technologies criteria.

\subsection{Case Study Sensitivity Analysis}

Every singular user of the BiogasApp_EDSS may give different importance to economic, environmental and operational criteria in the decision-making. According to this particularity, the user gives a relative weight to every criterion and obtains a ranking of the alternative treatment technologies. Sensitivity analysis is used to evaluate the influence of the weight repartition in multi-criteria analysis over the ranking of technologies obtained. Therefore, the influence of economic, operational, social and environmental criteria can be fully asset by the K-B decision support.

In the initial scenario proposed (i: Section 3.2) the total weight (100) is equally split among the four criteria considered. Next four alternative scenarios (Table 4, a-d) were created doubling the weight (referred as scenarios $+100 \%$ ) of one criterion $(25 \times 2)$ respect the initial scenario and splitting the residual weight among the other criteria (50/3). The last four scenarios (Table 4, a'-d') were obtained halving the weight (referred as scenarios $-50 \%$ ) of one criterion (25/2) and splitting the rest among the others (87.5/3). Thus, when running the BiogasApp_EDSS at different scenarios the importance of the user's sensitivity can be evaluated.

Table 4. Given to criteria selected to run the case-study validation (i) and the sensitivity analysis (a-d').

\begin{tabular}{|c|c|c|c|c|c|c|c|c|c|}
\hline \multirow{2}{*}{ Criteria } & \multirow{2}{*}{$\begin{array}{c}\text { Initial } \\
\text { Scenario } \\
\text { i }\end{array}$} & \multicolumn{4}{|c|}{ Scenarios $+\mathbf{1 0 0} \%$} & \multicolumn{4}{|c|}{ Scenarios $-50 \%$} \\
\hline & & $\mathbf{a}$ & $\mathbf{b}$ & c & d & $a^{\prime}$ & $\mathbf{b}^{\prime}$ & $\mathbf{c}^{\prime}$ & $d^{\prime}$ \\
\hline CAPEX & 25 & 50.0 & 16.7 & 16.7 & 16.7 & 12.5 & 29.2 & 29.2 & 29.2 \\
\hline OPEX & 25 & 16.7 & 50.0 & 16.7 & 16.7 & 29.2 & 12.5 & 29.2 & 29.2 \\
\hline $\begin{array}{c}\text { Stage of } \\
\text { development }\end{array}$ & 25 & 16.7 & 16.7 & 50.0 & 16.7 & 29.2 & 29.2 & 12.5 & 29.2 \\
\hline Removal efficiency & 25 & 16.7 & 16.7 & 16.7 & 50.0 & 29.2 & 29.2 & 29.2 & 12.5 \\
\hline
\end{tabular}

\section{Results and Discussion}

\subsection{BiogasApp_EDSS Evaluation}

The BiogasApp_EDSS was used to study the technologies that can be applied to treat the case-study raw biogas (Table 3). Flowrate $\left(110 \mathrm{~m}^{3} \mathrm{~h}^{-1}\right)$ was used by the tool as the first filter for discarding those upgrading technologies that require higher volume of biogas. Technologies getting past this filter are plotted in Figure 4, where the bubble size depends on the removal efficiency: the bigger the bubble the higher the efficiency. The rating of the criteria plotted in this example are CAPEX and OPEX, where higher values indicate lower costs. 


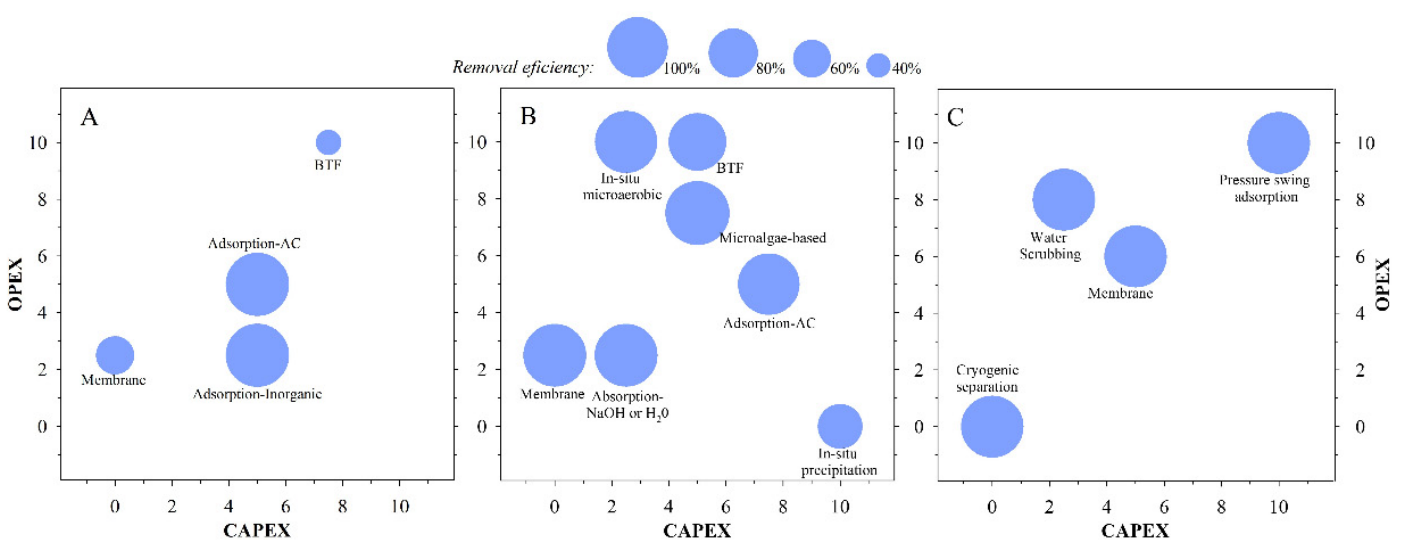

Figure 4. Evaluation of the technologies suggested by the BiogasApp_EDSS for (A) siloxanes removal; (B) $\mathrm{H}_{2} \mathrm{~S}$ removal; and C) $\mathrm{CH}_{4}$ enrichment, regarding removal efficiency, CAPEX, and OPEX.

In the case of siloxanes (Figure 4A), four technologies can be used with the gas flowrate of the case study. Adsorption onto activated carbon is one of the technologies with the highest overall removal efficiency, although it has a limited efficiency for small siloxane molecules, such as hexamethyldisiloxane [49]. However, the frequently required replacement of the exhausted adsorbent beds [24] increase the operational costs associated, obtaining a score of just 5 in OPEX criterion. Inorganic adsorbents $[45,50]$ are not only more expensive than activated carbon, but also the lifespan of the adsorbent bed is shorter, which considerably increases the OPEX ( 2.5 points). In the contrary, biotrickling filters have much lower operation costs compared to AC, obtaining a score of 10 . Therefore, biotrickling filter is the most suitable technology in terms of economic criteria obtaining the highest score among the available technologies. However, its capacity of removing siloxanes would be as high as $40 \%$ due to a scarce mass transfer from gas to the liquid phase [46]. Further research is required for enhancing this biological technology towards siloxanes. On the other hand, the low score that membranes receive indicate not only significant operational ( 2.5 points) and investment costs $(0$ points) but also lower RE than adsorption processes $(60 \%)$ at the current stage of development of this technology [47].

When it comes to $\mathrm{H}_{2} \mathrm{~S}$ abatement (Figure $4 \mathrm{~B}$ ), there is a wide spectrum of technologies that can cope with the flowrate provided. In terms of removal efficiency, the best alternative identified by the BiogasApp_EDSS is the microalgae-based technology, which has been reported to remove $100 \%$ [29]. In situ precipitation with iron salts is the technology with the lowest CAPEX (10 points), but relatively high OPEX (0 points) due to the demand on chemical substances. Membranes and absorption technologies are the overall lowest punctuated technologies, since they require high investment and operational costs. $\mathrm{H}_{2} \mathrm{~S}$ removal biotechnologies, such as biotrickling filter (BTF) and microaerobic oxidation, are interesting solutions in terms of OPEX, where they both obtained 10 points, while demonstrating high removal efficiencies $[16,18,29]$.

Figure $4 \mathrm{C}$ shows the technologies capable of separating $\mathrm{CO}_{2}$ obtaining methane-rich effluents. The technologies considered in the figure obtain ca. $97 \%$ of $\mathrm{CH}_{4}$ in effluent composition, hence the same bubble size for each one $[12,27,28]$. Therefore, economic criterion is used for choosing the best candidate, which in this case is pressure swing adsorption, showing the highest scores for economic criteria, while cryogenic separation is still an expensive technology.

\subsection{Case Study Validation}

The composition of the biogas mixture generated in the case study WWTP is described in Table 3. The energy cogeneration installation of the WWTP is equipped with three CR65 microturbines (Capstone Turbine Corporation), which biogas quality requirement is presented in Table 1. Accordingly, siloxane removal is the priority treatment that must be taken into consideration. The system was firstly run giving the criteria defined as initial scenario in Table 4 . 
The treatment technologies suggested by the EDSS are gathered and ranked in Table 5 with their final scores and effluent siloxane concentration calculated. Technologies with neither rank number nor total score did not accomplish the pre-screening requirements to be feasible for this case study: fluidized bed adsorption, scrubbing, and deep chilling are appropriated for plants generating flowrates starting at $500 \mathrm{~m}^{3} \mathrm{~h}^{-1}$. By contrast, BTF and membranes cannot obtain the effluent requirements for the installed microturbines $\left(0.03 \mathrm{mg} \mathrm{m}^{-3}\right)$ although they can work at the indicated flowrate.

Table 5. Treatment alternatives proposed by BiogasApp_EDSS, rating obtained in each considered criterion, total score obtained considering same weight for each criterion ( $25 \%$ each) and effluent concentration calculated.

\begin{tabular}{|c|c|c|c|c|c|c|c|}
\hline Rank n ${ }^{\circ}$ & Technology & CAPEX & OPEX & $\begin{array}{c}\text { Stage of } \\
\text { Development }\end{array}$ & $\begin{array}{l}\text { Removal } \\
\text { Efficiency * }\end{array}$ & $\begin{array}{l}\text { Total } \\
\text { Score }\end{array}$ & $\begin{array}{c}\text { Effluent } \\
\left(\mathrm{mg} \mathrm{m}^{-3}\right)\end{array}$ \\
\hline 1 & $\begin{array}{c}\text { Adsorption-activated } \\
\text { carbon (AC) }\end{array}$ & 5 & 5 & 10 & 9.8 & 7.5 & 0.01 \\
\hline 2 & Adsorption-inorganic & 5 & 2.5 & 0 & 9.8 & 4.3 & 0.01 \\
\hline- & BTF & 7.5 & 10 & 2.5 & 0 & 5.0 & $>0.03$ \\
\hline- & Membranes & 0 & 2.5 & 2.5 & 3.5 & 2.1 & $>0.03$ \\
\hline- & Fluid. bed adsorption & 2.5 & 5 & 2.5 & 9,8 & n.f. & - \\
\hline- & Deep chilling & 0 & 0 & 7.5 & 7.5 & n.f. & - \\
\hline- & Absorption-organic & 0 & 0 & 10 & 10 & n.f. & - \\
\hline- & Absorption—acids & 0 & 0 & 0 & 3.5 & n.f. & - \\
\hline
\end{tabular}

n.f.: Non-feasible technologies are not scored. ${ }^{*}$ Quantitative data-values normalized according to Equation (1).

In this event, adsorption is the technology that passed the pre-screening. Activated carbon was the overall best-ranked adsorbent, which corresponds to the treatment applied in the WWTP for siloxanes removal.

In the criterion "stage of development", adsorption onto AC obtained the highest score since it is the technology most widely used at industrial scale nowadays. Other technologies currently used in lower magnitude are deep chilling and membranes, while the rest of the reviewed technologies are still under development at a lab scale or pilot scale stage [1].

Regarding removal efficiencies, inorganic adsorbents (zeolites or silica gel) are close competitors to $\mathrm{AC}$ as porous materials for siloxane removal, however few studies have been published so far. Silica gel showed higher performance than zeolites $[45,51]$, which are more expensive. Consequently, OPEX are higher when dealing with this type of adsorbents over AC, as previously discussed. High removal efficiencies are reported for fluidized bed adsorption and absorption in organic solvents [29] but are still not widely implemented.

It needs to be highlighted that activated carbon filters require pre-treatment when raw biogas is saturated with water because the presence of humidity notably reduces the adsorption capacity, and so the lifespan of the adsorbent material [44]. The BiogasApp_EDSS can relate siloxane adsorption into $\mathrm{AC}$ with the presence of moisture in the biogas and alert that a pre-treatment step is required to apply this technology. However, since no weight was given to the "pre-treatment necessity" criterion, its need did not affect the final score of the technology. Overall, the BiogasApp_EDSS proposed treatment matched the technology applied in the case-study facility.

\subsection{Case Study Sensitivity Analysis}

Sensitivity analysis was performed to study the influence of the user over the score obtained for three siloxane removal technologies: Adsorption on activated carbon, adsorption on inorganic adsorbents and biological removal through biotrickling filters. Although BTF did not reach the effluent concentration required for microturbines, it was considered in the sensitivity analysis to explore the advantages and disadvantages of biological vs. adsorption technologies.

This evaluation enables not only to consider different kind of criteria but also to give them a range of importance to identify the key criteria and facilitate a decision-making adjusted to user's preferences. To do so, weight of every criteria was modified as described in Table 4 and compared to the original 
analysis in Table 5 . The score obtained by the considered technologies in every scenario are shown in Figure 5.

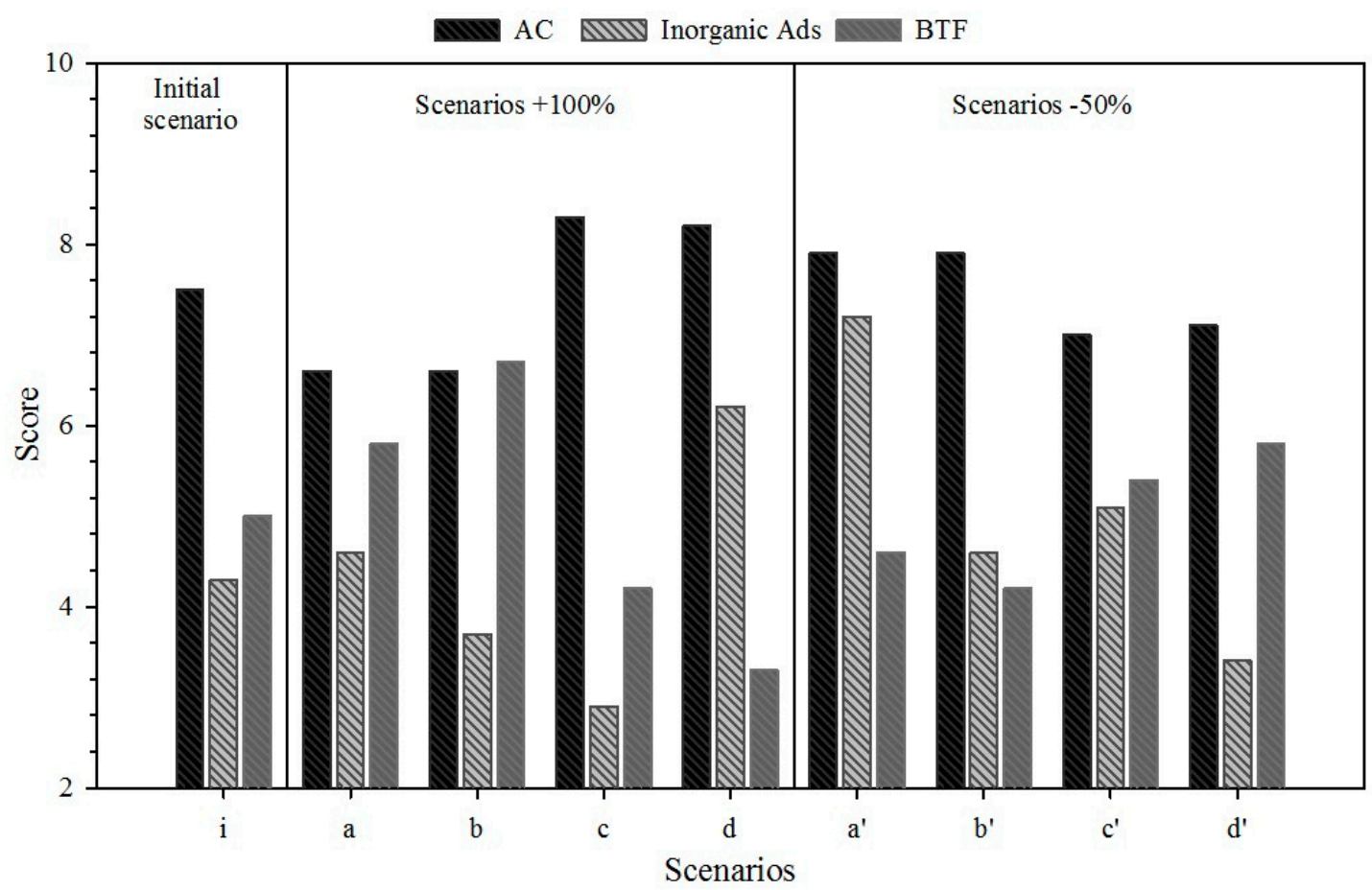

Figure 5. Scores resulting from the sensitivity analysis in the scenarios described in Table 4 for selected siloxane removal technologies (activated carbon, inorganic adsorbents and biotrickling filter).

Activated carbon adsorption is the best-ranked technology in the initial scenario, i.e., when the same weight is given to every criterion. This technology has the maximum score in "Stage of development" criteria, since it has been largely investigated. Removal efficiency is another strength of this technology, even though some siloxane molecules are not retained for long time in activated carbon filters. In the contrary, removal efficiency and stage of development are the main drawbacks of BTF, since biological removal of siloxanes is not a mature technology yet.

Nonetheless, when economic criteria are concerned, BTF obtains the highest OPEX score, being the highest ranked technology in scenario $b$. Therefore, the biological removal of siloxanes through biotrickling filters is a promising technology under development that might overcome adsorption on activated carbon in the short term if further research is carried out. Moreover, the combination of inert packing material (commonly used in BTF) together with activated carbon might be an interesting solution to be explored in future work. This new technology might reduce the high OPEX of AC alone and increase the removal efficiency of the BTF.

AC filters and BTF can be used for removing siloxanes and $\mathrm{H}_{2} \mathrm{~S}$ separately. The possibility of eliminating both pollutants in one hybrid operation unit could be also regarded by the EDSS. However, there is no data available, so far, concerning the removal of both target compounds in the same unit.

\section{Conclusions}

To the best of the authors' knowledge, this work presents the first EDSS developed for the biogas upgrading field. The present paper presents and describes the development of an EDSS for biogas treatment in WWTPs for its conversion into heat and energy, and further upgraded into biomethane for grid injection or vehicle fuel. This tool is intended to be easily updated with new bibliographic data, since many technologies are still under research.

The EDSS was validated for siloxanes' removal within a real case-study and demonstrated to be a useful tool in the decision-making process since the treatment technology proposed matched the one 
applied in the facility. The EDSS allowed the user to anticipate the effluent concentrations, and through a wide range of environmental, economic and technical criteria, analyze numerous scenarios and parameters simultaneously according to the preferences. The sensitivity analysis performed allowed the identification of key criteria for the differentiation of the several technology alternatives proposed. For instance, activated carbon filters are preferred when low concentrations of siloxanes are desired. However, when sustainability concerns are considered as well as economical criteria, biotechnologies are potential technologies.

Supplementary Materials: The following are available online at http://www.mdpi.com/1996-1073/12/8/1546/s1.

Author Contributions: Developing of the EDSS: E.S.-C. and A.C.; Validation of the EDSS: E.S.-C. and A.C.; Case-study evaluation and sensitivity analysis: E.S.-C., A.C.-C. and H.M.; Writing of the article: E.S.-C., A.C., A.C.-C. and H.M.; Revision of the article content: all of the authors. Supervision of the work: M.J.M., M.P. and H.M.

Funding: This work was cofunded by the Ministerio de Economica y Competitividad (Spain - CTQ2014-53718-R), FEDER and University of Girona. ES-C thanks Universitat de Girona for his predoctoral grant (IFUdG-2015/51). AC-C acknowledges support from the European Union's Horizon 2020 research and innovation programme under the Marie Skłodowska-Curie grant agreement No 712949 (TECNIOspring PLUS) and from the Agency for Business Competitiveness of the Government of Catalonia (TECSPR16-1-0045). HM acknowledges support from the Spanish Ministry of Economy, Industry and Competitiveness for co-funding this study (IJCI-2015-23159). The authors also want to thank the plant manager of the case-study WWTP for all the data and support. LEQUIA has been recognized as consolidated research group by the Catalan Government (2017-SGR-1552).

Conflicts of Interest: The authors declare no conflict of interest.

\section{Abbreviations}

$\begin{array}{ll}\text { EDSS } & \text { Environmental decision support system } \\ \text { GHG } & \text { Greenhouse gas } \\ \text { ECS } & \text { Energy conversion system } \\ \text { WWTP } & \text { Wastewater treatment plant } \\ \text { AC } & \text { Activated carbon } \\ \text { BTF } & \text { Biotrickling filter } \\ \text { ICE } & \text { Internal combustion engine } \\ \text { PAFC } & \text { Phosphoric acid fuel cell } \\ \text { SOFC } & \text { Solid oxide fuel cell } \\ \text { RE } & \text { Removal efficiency } \\ \text { CAPEX } & \text { Capital expenses } \\ \text { OPEX } & \text { Operating expenses }\end{array}$

\section{References}

1. Ullah Khan, I.; Hafiz Dzarfan Othman, M.; Hashim, H.; Matsuura, T.; Ismail, A.F.; Rezaei-DashtArzhandi, M.; Wan Azelee, I. Biogas as a renewable energy fuel-A review of biogas upgrading, utilisation and storage. Energy Convers. Manag. 2017, 150, 277-294. [CrossRef]

2. Baccioli, A.; Ferrari, L.; Guiller, R.; Yousfi, O.; Vizza, F.; Desideri, U. Feasibility Analysis of Bio-Methane Production in a Biogas Plant: A Case Study. Energies 2019, 12, 473. [CrossRef]

3. Patinvoh, R.J.; Osadolor, O.A.; Chandolias, K.; Sárvári Horváth, I.; Taherzadeh, M.J. Innovative pretreatment strategies for biogas production. Bioresour. Technol. 2017, 224, 13-24. [CrossRef]

4. Pavi, S.; Kramer, L.E.; Gomes, L.P.; Miranda, L.A.S. Biogas production from co-digestion of organic fraction of municipal solid waste and fruit and vegetable waste. Bioresour. Technol. 2017, 228, 362-367. [CrossRef]

5. Florio, C.; Fiorentino, G.; Corcelli, F.; Ulgiati, S.; Dumontet, S.; Güsewell, J.; Eltrop, L. A Life Cycle Assessment of Biomethane Production from Waste Feedstock Through Different Upgrading Technologies. Energies 2019, 12, 718. [CrossRef]

6. Papurello, D.; Silvestri, S.; Tomasi, L.; Belcari, I.; Biasioli, F.; Santarelli, M. Biowaste for SOFCs. Energy Procedia 2016, 101, 424-431. 
7. Felca, A.T.A.; Barros, R.M.; Tiago Filho, G.L.; dos Santos, I.F.S.; Ribeiro, E.M. Analysis of biogas produced by the anaerobic digestion of sludge generated at wastewater treatment plants in the South of Minas Gerais, Brazil as a potential energy source. Sustain. Cities Soc. 2018, 41, 139-153. [CrossRef]

8. Papurello, D.; Tomasi, L.; Silvestri, S.; Belcari, I.; Santarelli, M.; Smeacetto, F.; Biasioli, F. Biogas trace compound removal with ashes using proton transfer reaction time-of-flight mass spectrometry as innovative detection tool. Fuel Process. Technol. 2016, 145, 62-75. [CrossRef]

9. Arrhenius, K.; Fischer, A.; Büker, O. Methods for Sampling Biogas and Biomethane on Adsorbent Tubes after Collection in Gas Bags. Appl. Sci. 2019, 9, 1171. [CrossRef]

10. Raheem, A.; Sikarwar, V.S.; He, J.; Dastyar, W.; Dionysiou, D.D.; Wang, W.; Zhao, M. Opportunities and Challenges in Sustainable Treatment and Resource Reuse of Sewage Sludge: A Review. Chem. Eng. J. 2017. [CrossRef]

11. Papurello, D.; Lanzini, A. SOFC single cells fed by biogas: Experimental tests with trace contaminants. Waste Manag. 2018, 72, 306-312. [CrossRef] [PubMed]

12. Budzianowski, W.M.; Wylock, C.E.; Marciniak, P.A. Power requirements of biogas upgrading by water scrubbing and biomethane compression: Comparative analysis of various plant configurations. Energy Convers. Manag. 2017, 141, 2-19. [CrossRef]

13. Baldinelli, A.; Barelli, L.; Bidini, G. Upgrading versus reforming: An energy and exergy analysis of two Solid Oxide Fuel Cell-based systems for a convenient biogas-to-electricity conversion. Energy Convers. Manag. 2017, 138, 360-374. [CrossRef]

14. Lyng, K.-A.; Brekke, A. Environmental Life Cycle Assessment of Biogas as a Fuel for Transport Compared with Alternative Fuels. Energies 2019, 12, 532. [CrossRef]

15. Rasi, S.; Läntelä, J.; Rintala, J. Trace compounds affecting biogas energy utilization-A review. Energy Convers. Manag. 2011, 52, 3369-3375. [CrossRef]

16. Aguilera, P.G.; Gutiérrez Ortiz, F.J. Techno-economic assessment of biogas plant upgrading by adsorption of hydrogen sulfide on treated sewage-sludge. Energy Convers. Manag. 2016, 126, 411-420. [CrossRef]

17. De Arespacochaga, N.; Valderrama, C.; Mesa, C.; Bouchy, L.; Cortina, J.L. Biogas biological desulphurisation under extremely acidic conditions for energetic valorisation in Solid Oxide Fuel Cells. Chem. Eng. J. 2014, 255, 677-685. [CrossRef]

18. Fortuny, M.; Baeza, J.A.; Gamisans, X.; Casas, C.; Lafuente, J.; Deshusses, M.A.; Gabriel, D. Biological sweetening of energy gases mimics in biotrickling filters. Chemosphere 2008, 71, 10-17. [CrossRef] [PubMed]

19. Papurello, D.; Santarelli, M.; Fiorilli, S. Physical activation of waste-derived materials for biogas cleaning. Energies 2018, 11, 2338. [CrossRef]

20. De Arespacochaga, N.; Valderrama, C.; Raich-Montiu, J.; Crest, M.; Mehta, S.; Cortina, J.L. Understanding the effects of the origin, occurrence, monitoring, control, fate and removal of siloxanes on the energetic valorization of sewage biogas-A review. Renew. Sustain. Energy Rev. 2015, 52, 366-381. [CrossRef]

21. Dewil, R.; Appels, L.; Baeyens, J. Energy use of biogas hampered by the presence of siloxanes. Energy Convers. Manag. 2006, 47, 1711-1722. [CrossRef]

22. De Arespacochaga, N.; Valderrama, C.; Mesa, C.; Bouchy, L.; Cortina, J.L. Biogas deep clean-up based on adsorption technologies for Solid Oxide Fuel Cell applications. Chem. Eng. J. 2014, 255, 593-603. [CrossRef]

23. Cabrera-Codony, A.; Gonzalez-Olmos, R.; Martín, M.J.J. Regeneration of siloxane-exhausted activated carbon by advanced oxidation processes. J. Hazard. Mater. 2015, 285, 501-508. [CrossRef] [PubMed]

24. Santos-Clotas, E.; Cabrera-Codony, A.; Ruiz, B.; Fuente, E.; Martín, M.J. Sewage biogas efficient purification by means of lignocellulosic waste-based activated carbons. Bioresour. Technol. 2019, 275, 207-215. [CrossRef] [PubMed]

25. Soreanu, G. Insights into siloxane removal from biogas in biotrickling filters via process mapping-based analysis. Chemosphere 2016, 146, 539-546. [CrossRef]

26. Zhang, X.; Yan, J.; Li, H.; Chekani, S.; Liu, L. Investigation of thermal integration between biogas production and upgrading. Energy Convers. Manag. 2015, 102, 131-139. [CrossRef]

27. Scholz, M.; Melin, T.; Wessling, M. Transforming biogas into biomethane using membrane technology. Renew. Sustain. Energy Rev. 2013, 17, 199-212. [CrossRef]

28. Andriani, D.; Wresta, A.; Atmaja, T.D.; Saepudin, A. A Review on Optimization Production and Upgrading Biogas Through $\mathrm{CO}_{2}$ Removal Using Various Techniques. Appl. Biochem. Biotechnol. 2014, 172, 1909-1928. [CrossRef] 
29. Muñoz, R.; Meier, L.; Diaz, I.; Jeison, D. A review on the state-of-the-art of physical/chemical and biological technologies for biogas upgrading. Rev. Environ. Sci. Biotechnol. 2015, 14, 727-759. [CrossRef]

30. Kumar, M.; Sundaram, S.; Gnansounou, E.; Larroche, C.; Thakur, I.S. Carbon dioxide capture, storage and production of biofuel and biomaterials by bacteria: A review. Bioresour. Technol. 2018, 247, 1059-1068. [CrossRef]

31. Collet, P.; Flottes, E.; Favre, A.; Raynal, L.; Pierre, H.; Capela, S.; Peregrina, C. Techno-economic and Life Cycle Assessment of methane production via biogas upgrading and power to gas technology. Appl. Energy 2017, 192, 282-295. [CrossRef]

32. Awe, O.W.; Zhao, Y.; Nzihou, A.; Minh, D.P.; Lyczko, N. A Review of Biogas Utilisation, Purification and Upgrading Technologies. Waste Biomass Valoriz. 2017, 8, 267-283. [CrossRef]

33. Bauer, F.; Hulteberg, C.; Persson, T.; Tamm, D. Biogas upgrading-Review of commercial technologies. Swedish Gas Technol. Centre SGC Raport, 2013. Available online: http://www.sgc.se/ckfinder/userfiles/files/SGC270.pdf (accessed on 1 March 2018).

34. Poch, M.; Comas, J.; Rodríguez-Roda, I.; Sànchez-Marrè, M.; Cortés, U. Designing and building real environmental decision support systems. Environ. Model. Softw. 2004, 19, 857-873. [CrossRef]

35. Hamouda, M.A.; Anderson, W.B.; Huck, P.M. Decision support systems in water and wastewater treatment process selection and design: A review. Water Sci. Technol. 2009, 60, 1767-1770. [CrossRef]

36. Garrido-Baserba, M.; Molinos-Senante, M.; Abelleira-Pereira, J.M.; Fdez-Güelfo, L.A.; Poch, M.; Hernández-Sancho, F. Selecting sewage sludge treatment alternatives in modern wastewater treatment plants using environmental decision support systems. J. Clean. Prod. 2015, 107, 410-419. [CrossRef]

37. Garrido-Baserba, M.; Reif, R.; Hernández, F.; Poch, M. Implementation of a knowledge-based methodology in a decision support system for the design of suitable wastewater treatment process flow diagrams. $J$. Environ. Manag. 2012, 112, 384-391. [CrossRef]

38. Castillo, A.; Porro, J.; Garrido-Baserba, M.; Rosso, D.; Renzi, D.; Fatone, F.; Gómez, V.; Comas, J.; Poch, M. Validation of a decision support tool for wastewater treatment selection. J. Environ. Manag. 2016, 184, 409-418. [CrossRef]

39. Raseman, W.J.; Kasprzyk, J.R.; Rosario-Ortiz, F.L.; Stewart, J.R.; Livneh, B. Emerging investigators series: A critical review of decision support systems for water treatment: Making the case for incorporating climate change and climate extremes. Environ. Sci. Water Res. Technol. 2017, 3, 18-36. [CrossRef]

40. Billig, E.; Thrän, D. Evaluation of biomethane technologies in Europe-Technical concepts under the scope of a Delphi-Survey embedded in a multi-criteria analysis. Energy 2016, 114, 1176-1186. [CrossRef]

41. Estrada, J.M.; Kraakman, N.J.R.; Lebrero, R.; Muñoz, R. A sensitivity analysis of process design parameters, commodity prices and robustness on the economics of odour abatement technologies. Biotechnol. Adv. 2012, 30, 1354-1363. [CrossRef]

42. BOE-A-2013-185 Resolución de 21 de Diciembre de 2012, de la Dirección General de Política Energética y Minas, por la que se Modifica el Protocolo de Detalle PD-01; Agencia Estatal Boletin Oficial Del Estado: Madrid, Spain, 2013; pp. 889-892.

43. Ajhar, M.; Travesset, M.; Yüce, S.; Melin, T. Siloxane removal from landfill and digester gas-A technology overview. Bioresour. Technol. 2010, 101, 2913-2923. [CrossRef] [PubMed]

44. Cabrera-Codony, A.; Montes-Morán, M.A.; Sánchez-Polo, M.; Martín, M.J.; Gonzalez-Olmos, R. Biogas upgrading: Optimal activated carbon properties for siloxane removal. Environ. Sci. Technol. 2014, 48, 7187-7195. [CrossRef]

45. Cabrera-Codony, A.; Georgi, A.; Gonzalez-Olmos, R.; Valdés, H.; Martín, M.J. Zeolites as recyclable adsorbents/catalysts for biogas upgrading: Removal of octamethylcyclotetrasiloxane. Chem. Eng. J. 2017, 307. [CrossRef]

46. Popat, S.C.; Deshusses, M.A. Biological removal of siloxanes from landfill and digester gases: Opportunities and challenges. Environ. Sci. Technol. 2008, 42, 8510-8515. [CrossRef]

47. Ajhar, M.; Bannwarth, S.; Stollenwerk, K.H.; Spalding, G.; Yüce, S.; Wessling, M.; Melin, T. Siloxane removal using silicone-rubber membranes. Sep. Purif. Technol. 2012, 89, 234-244. [CrossRef]

48. Peredo-Mancilla, D.; Ghouma, I.; Hort, C.; Ghimbeu, C.M.; Jeguirim, M.; Bessieres, D. $\mathrm{CO}_{2}$ and $\mathrm{CH}_{2}$ adsorption behavior of biomass-based activated carbons. Energies 2018, 11, 3136. [CrossRef]

49. Cabrera-Codony, A.; Santos-Clotas, E.; Ania, C.O.; Martín, M.J. Competitive siloxane adsorption in multicomponent gas streams for biogas upgrading. Chem. Eng. J. 2018, 344, 565-573. [CrossRef] 
50. Jiang, T.; Zhong, W.; Jafari, T.; Du, S.; He, J.; Fu, Y.J.; Singh, P.; Suib, S.L. Siloxane D4 adsorption by mesoporous aluminosilicates. Chem. Eng. J. 2016, 289, 356-364. [CrossRef]

51. Sigot, L.; Ducom, G.; Benadda, B.; Labouré, C. Adsorption of octamethylcyclotetrasiloxane on silica gel for biogas purification. Fuel 2014, 135, 205-209. [CrossRef]

(C) 2019 by the authors. Licensee MDPI, Basel, Switzerland. This article is an open access article distributed under the terms and conditions of the Creative Commons Attribution (CC BY) license (http://creativecommons.org/licenses/by/4.0/). 